AKADEMIKA

JURNAL ILMIAH

\title{
URGENSI MATA KULIAH PENDIDIKAN KARAKTER DI FAKULTAS KEGURUAN DAN ILMU PENDIDIKAN DALAM KONTELASI GURU SEBAGAI ROLE MODEL BAGI PESERTA DIDIK
}

\author{
Irmawati Duko Ishak \\ Program Studi Pendidikan Guru sekolah Dasar Universitas Muhammadiyah Gorontalo \\ e-mail: Irmawatiishak@gmail.com
}

\begin{abstract}
The formulation of the problem in this study is that the Indonesian government emphasizes the implementation of character education in the learning process in schools. in practice there are reductions that result in the practice of character education not being comprehensive, because prioritizing the teaching of values is more emphasis on the cognitive side. This research is a qualitative descriptive study conducted at the Teacher Training and Education Faculty of Gorontalo State University. The source of the data uses a purposive sample that focuses on selected informants. Data collection is needed through observation, interviews and documentation studies. The data analysis technique used in this study is interactive analysis with 4 components of analysis, namely: 1) data collection, 2) data reduction, 3) data presentation, and 4) conclusion. The results of the research data are as follows: 1) Based on the results of the interviews, it was concluded that $100 \%$ of the speakers had heard the term character education. 2) $97 \%$ of informants do not understand about $97 \%$ character education. The resource person does not understand the implementation of $100 \%$ character education $99 \%$ of speakers do not know how to teach character education to students.
\end{abstract}

Keywords: Teacher; Character Education; Model Role 


\begin{abstract}
Abstrak
Rumusan masalah pada penelitian ini adalah pemerintah Indonesia memberi penekanan pada pelaksanaan pendidikan karakter dalam proses pembelajaran di sekolah. pada praktiknya terjadi reduksi-reduksi yang mengakibatkan praktik pendidikan karakter tidak komprehensif, karena lebih mengedepankan pada pengajaran nilai-nilai saja yakni penekanan lebih pada sisi kognitif. Penelitian ini merupakan penelitian deskriptif kualitatif yang dilaksanakan dilakukan di Fakultas keguruan dan Ilmu Pendidikan Universitas Negeri Gorontalo. Sumber data menggunakan sampel purposif (purposive sample) yang fokus pada informan-informan terpilih. Pengumpulan data yang diperlukan melalui observasi, wawancara dan studi dokumentasi. Teknik analisis data yang digunakan dalam penelitian ini adalah analisis interaktif dengan 4 komponen analisis yaitu: 1) pengumpulan data, 2) reduksi data, 3) penyajian data, dan 4) penarikan kesimpulan. Data hasil penelitian sebagai berikut: 1) Berdasarkan hasil wawancara diperoleh kesimpulan bahwa $100 \%$ narasumber pernah mendengar istilah pendidikan karakter. 2) 97\% narasumber tidak paham mengenai pendidikan karakter $97 \%$ narasumber tidak paham implementasi pendidikan karakter $100 \%$ narasumber ingin mengajarkan pendidikan karakter terhadap siswa jika nanti mengajar disekolah. 99\% narasumber tidak tau cara mengajarkan pendidikan karakter kepada siswa.
\end{abstract}

Kata Kunci : Guru; Pendidikan Karakter; Role Model

\section{PENDAHULUAN}

Pendidikan adalah modal utama dalam upaya peningkatan kualitas sumber daya manusia. Pendidikan merupakan ujung tombak pembentukan insan cindikia yang tidak hanya cerdas juga berkarakter mulia.guru sebagai stackholder kegiatan pendidikan harus memiliki Orientasi pada penanaman nilainilai yang membentuk karakter dan kepribadian peserta didik.
Secara filosofi, pendidikan bertujuan memanusiakan manusia. Pendidikan tidak hanya berfokus pada penyampaian materi yang memiliki tujuan semata-mata meningkatkan kemampuan intelektual peserta didik, tetapi harus dapat membangun dan mengembangkan karakter pembelajar dalam meningkatkan kemampuan pengelolaan emosi.

Dalam Undang-undang (UU) No.20, tahun 2003 tentang Sistem 
PendidikanNasional pasal 3 dinyatakan bahwa Pendidikan nasional berfungsi mengembangkankemampuan

dan membentuk watak serta peradaban bangsa yang bermartabat dalam rangkamencerdaskan kehidupan bangsa, bertujuan untuk berkembangnya potensi peserta didikagar menjadi manusia yang beriman dan bertaqwa kepada Tuhan Yang Maha Esa,berakhlak mulia, sehat, berilmu, cakap, kreatif, mandiri, dan menjadi warga Negara yangdemokratis serta bertanggung jawab. Sehingga lahir anak-anak bangsa yang kreatif yang mampu mengemban tugas sebagai agen perubahan dalam masyarakat serta menjadi generasi dengan pemimpin yang meneruskan cita-cita perjuangan bangsa.

Sehubungan dengan ketetapan UUD dan UU tentang Sisdiknas serta tujuan pendidikan nasional yang telah di tetapkan oleh pemerintah bahwa pendidikan di masa yang akan datang ini harus memiliki mutu dan berkualitas dibanding dengan pelaksanaan pendidikan yang telah berlangsung saat sekarang ini. Maka perlu ditegaskan bahwa Keputusan Presiden RI No 1 Tahun 2010 setiap jenjang pendidikan di Indonesia harus melaksanakan pendidikankarakter.

Lembaga pendidikan dan guru dewasaini dihadapkan pada tuntutankewajiban menyiapkan peserta didik yang tidak hanya cerdas secara akademik tetapi juga mampu menghadapi dinamikaperubahanyang berkembang dengansangat cepat.Perubahan tidak hanya terkait peningkatan ilmu pengetahuandan teknologi, juga menyentuhpergeseran aspek nilaidan moral dalam kehidupan masyarakat.

Menurut Goleman dalam Leonie Francisca (2016), keberhasilan seseorang di masyarakat, $80 \%$ dipengaruhi oleh kecerdasan emosi, dan hanya $20 \%$ ditentukan oleh kecerdasan intelektual. Anak yang memiliki masalah dalam kecerdasan emosinya akan mengalami kesulitan belajar, bergaul, dan tidak dapat mengontrol emosi mereka. Permasalahan ini terlihat sejak usia anak masih prasekolah dan dapat terbawa sampai usia dewasa. Sebaliknya, seorang anak yang berkarakter atau mempunyai kecerdasan emosi tinggi cenderung terhindar dari masalah-masalah, seperti kenakalan, tawuran, narkoba, miras, perilaku seks bebas, dan perilaku negatif lainnya.

Dewasa ini, Pemerintah Indonesia memberi penekanan pada pelaksanaanpendidikan karakter dalam proses pembelajaran di sekolah. Hanya saja, pada praktiknya terjadi reduksireduksi yang mengakibatkan praktik 
pendidikan karakter tidak komprehensif, karena lebih mengedepankan pada pengajaran nilai-nilai saja yakni penekanan lebih padasisi kognitif. Pada proses pengembangan karakter, faktor yang dapat dikembangkan adalah pada pembentukan lingkungan. Pembentukan lingkungan menjadi sangat penting karena pada dasarnya karakter adalah kualitas pribadi seseorang yang terbentuk melalui proses belajar (Raka dkk, 2011).

Universitas Negeri Gorontalo memiliki sejarah sebagai fakultas pendidikan sejak tahun 1963 yakni dikenal dengan FKIP Universitas Sulawesi Utara-Tengah.Temuan awal peneliti, sebagai Perguruan Tinggi yang memiliki Fakultas IImu pendidikan terbesar dan terbaik di Gorontalo Universitas Negeri Gorontalo Belum menjadikan Pendidikan Karakter sebagai mata kuliah dalam kurikulum pendidikan.Urgenitas Pendidikan karakter dalam mata kuliah dirasa mampu membentuk karakter positif dan teladan bagi mahasiswa yang merupakan calon guru. Kondisi tersebut membuat peneliti merasa perlu melakukan penelitian mendalam terkait bagaimana pemahaman pendidikan karakter mahasiswa Fakultas IImu Pendidikan, serta bagaimana cara mahasiswa tersebut mampu melakukan transfer nilainilai karakter dalam mata pelajaran.

\section{METODE PENELITIAN}

Penelitian ini adalah penelitian deskriptif melalui pendekatan kualitatifInteraktif.Didasarkan pada tujuan, penelitian deskriptif merupakan penelitian yang menggambarkan fenomena yang sedang berlangsung untuk membuat deskripsi, gambaran,faktual dan akurat mengenai fakta-fakta atau hubungan antara fenomena yang diselidiki (Nazir 2005).Sedangkan, bila dilihat dari perolehan dan pengolahan data, penelitian ini menggunakan pendekatan kualitatif interaktif yakni menggunakan teknik pengumpulan data langsung dari orang dalam lingkungan alamiahnya yang diharapkan mampu memberikan penjelasan secara terperinci tentang suatu fenomena (Nana Syaodih 2010).

Penelitian ini dilakukan di Universitas Negeri Gorontalo. Pemilihan lokasi penelitian disebabkan Universitas Negeri Gorontalo merupakan perguruan tinggi negeri yang memiliki Fakultas keguruan dengan jumlah mahasiswa paling banyak di Gorontalo.Selain itu Universitas Negeri Gorontalo memiliki sejarah sebagai fakultas pendidikan sejak tahun 1963 yakni dikenal dengan FKIP Universitas Sulawesi Utara-Tengah.Peneliti 
menemukan Universitas Negeri Gorontalo Belum menjadikan Pendidikan Karakter sebagai mata kuliah dalam kurikulum pendidikan.Waktu penelitian dilakuka selama tiga bulan, yaitu sejak bulan Januari 2018 sampai April 2018.

Sebagaimana dijelaskan Aan Komariah (2010), penelitian kualitatif tidak mengenal istilah populasi, dan sampel.Populasi atau sampel pada pendekatan kualitatif lebih tepat disebut sumber data pada situasi sosial (Social Situation) tertentu. Sedangkan menurut Spradley dalam Sugiyono (2011) Social situation terdiri atas tiga elemen yaitu : tempat (place), pelaku (actors), dan aktivitas (activity) yang berinteraksi secara sinergis. Maka penelitian ini, memiliki sumber data menggunakan sampel purposif (purposive sample) yang fokus pada informan-informan terpilih dengan kasus untuk studi yang bersifat mendalam

(Nana

2007).Sehingga data yang diperlukan

untuk mengetahui bagaimana pengetahuan mahasiswa Universitas Negeri Gorontalo terhadap pendidikan karakter adalah data yang dikumpulkan melalui observasi, wawancara dan studi dokumentasi.

Subjek penelitian atau informanpada penelitian ini adalah mahasiswa Fakultas IImu Pendidikan dengan jurusan yang berbeda.Yang diminta memberikan keterangan atau pendapat melalui wawancara secara langsung.

Teknik Analisis data

Teknik analisis data yang digunakan dalam penelitian ini adalah analisis interaktif dengan 4 komponen analisis yaitu: 1) pengumpulan data, 2) reduksi data, 3) penyajian data, dan 4) penarikan kesimpulan. Menurut Moleong (2004), "Analisis data adalah proses mengorganisasikan dan mengurutkan data kedalam pola, kategori, dan satuan uraian dasar sehingga dapat ditemukan tema dan tempat dirumuskan hipotesis kerja seperti yang disarankan oleh data". analisis data kualitatif dilakukan selama proses pengumpulan data dilapangan.

\section{HASIL PENELITIAN DAN PEMBAHASAN}

Wawancara dilaksanakan dengan menggunakan teknik purposive terhadap 30 orang mahasiswa sebagai narasumber.Wawancara dengan narasumber dilaksanakan selama dua minggu pemilihan narasumber dilakukan secara random tanpa melihat semester dan jurusan mahasiswa. Rincian narasumber yang diperoleh adalah 5 orang narasumber berasal dari jurusan pendidikan Olahraga, 7 orang dari jurusan 
Bimbingan Konseling, 10 orang jurusan PGSD, 4 orang dari jurusan manajemen pendidikan, dan 4 orang dari jurusan PAUD.

Data hasil penelitian diuraikan sebagai berikut :

1) Berdasarkan hasil wawancara diperoleh kesimpulan bahwa 100 $\%$ narasumber pernah mendengar istilah pendidikan karakter.

2) Berdasarkan hasil wawancara diperoleh data $97 \%$ narasumber tidak paham mengenai pendidikan karakter

3) Berdasarkan hasil wawancara diperoleh data $97 \%$ narasumber tidak paham implementasi pendidikan karakter

4) Berdasarkan hasil wawancara diperoleh data $100 \%$ narasumber ingin mengajarkan pendidikan karakter terhadap siswa jika nanti mengajar disekolah.

5) Berdasarkan hasil wawancara diperoleh kesimpulan bahwa $99 \%$ narasumber tidak tau cara mengajarkan pendidikan karakter kepada siswa.

Hasil penelitian ini menunjukkan bahwa hampir seluruh mahasiswa IImu Pendidikan Universitas Negeri Gorontalo tidak paham mengenai pendidikan karakter, tidak paham bagaimana implementasi pendidikan karakter dan tidak tau cara mengajarkan pendidikan karakter kepada siswa.data ini menggambarkan bahwa pengetahuan terkait pengembangan mahasiswa yang merupakan calon-calon guru bertentangan dengan konteks pencapaian tujuan pendidikan karakter, dimana guru merupakan ujung tombak keberhasilan pencapaian tujuan pendidikan karakter. Guru, merupakan sosok yang digugu dan ditiru, memiliki peran penting dalam terwujudnya proses pembentukan karakter peserta didik. Sebagaimana dikemukakan Suryadi (2011) dalam mengembangkan karakter peserta didik di sekolah, guru memiliki posisi paling utama dan strategis. Menurut Gunawan (2012), bahwa pendidikan karakter adalah segala sesuatu yang dilakukan guru, yang mampu mempengaruhi karakter peserta didik.

Mencermati pentingnya peran
guru terhadap pembentukan karakter
peserta didik, pendidikan untuk calon
guru yang berkarakter cerdas harus
didisain dengan lebih cermat. Mulai
dari penyaringan calon guru sudah dipilih
melalui mekanisme seleksi yang ketat,
transparan dan bermartabat, kurikulum
berbasis kompetensi dan soft skill,
pembelajaran berkarakter yang mendidik

Mencermati pentingnya peran peserta didik, pendidikan untuk calon guru yang berkarakter cerdas harus dari penyaringan calon guru sudah dipilih melalui mekanisme seleksi yang ketat, transparan dan bermartabat, kurikulum pembelajaran berkarakter yang mendidik 
dan memandirikan mahasiswa, penyediaan sarana dan prasarana termasuk dalam hal ini laboratorium yang menunjang pengembangan karakter mahasiswa dan dosen di Fakultas Keguruan dan IImu Pendidikan.

Dinamisasi perkembangan jaman menjadikan peran guru mengalami peningkatan, sebagai pendidik seorang guru harus bisa mempertahankan nilainilai positif.Sebagai Role Model guru harus memiliki karakter berkulitas, seperti komitmen dalam bekerja, menghargai perbedaan dan memiliki keterampilan yang baik dalam mengajar serta harus mampu menjadi teladan bagi peserta didik.

Mendukung peran guru dalam pembentukan karakter peserta didik, guru dituntut memahami dan memiliki karakter yang kuat serta mampu mentransfer penguatan dan motivasi terhadap peserta didik, maka integrasi pendidikan karakter dalam kegiatan perkuliahan di fakultas keguruan dirasa belum mampu melahirkan calon-calon guru yang berkarakter. Pendidikan karakter di Fakultas Keguruan harus diberikan secara terpadu sebagai mata kuliah, sehingga mahasiswa difakultas keguruan akan lebih memahami konsep-konsep pendidikan karakter, implementasi pendidikan karakter dan bagaimana membentuk kualitas karakter peserta didik disekolah.

\section{Urgensi Pendidikan Karakter Terhadap Guru}

Sebagai wahana pembelajaran, sekolah merupakan tempat potensial pelaksanaan pendidikan karakter.Sekolah tidak hanya bertanggung jawab untuk mencetak peserta didik yang unggul dalam ilmu pengetahuan dan teknologi, tetapi juga memiliki karakter unggul, dan kepribadian. di sekolah, guru memiliki peran utama. Guru merupakan garis depan terwujudnya pelaksanaan pendidikan karakter. Guru yang langsung berhadapan dengan peserta didik untuk mentransfer ilmu pengetahuan dan teknologi serta mendidik dengan nilai-nilai positif melalui bimbingan dan keteladanan (Kunandar, 2008).Guru, menurut Danin (2010), merupakan profesional dengan tugas utama mendidik, mengajar, membimbing, mengarahkan, melatih, menilai, dan mengevaluasi peserta didik.Karena begitu beratnya tugas, maka guru harus mempunyai beberapa kompetensi untuk melaksanakan tugasnya.Dalam Peraturan Pemerintah Nomor 19 tahun 2005, guru lembaga pendidikan non-formal, harus tetap mempunyai kompetensi pedagogis, kepribadian, sosial, dan 
profesional.Selain kompetensi guru guru-guru dengan pengalaman hidup tersebut, sangat penting bagi guru untuk yang berbeda.Kesulitan lain yang memiliki pemahaman mengenai dihadapi guru adalah dalam hal penilaian, pendidikan karakter. Setiap karakter yang Uji yang dilakukan terhadap peserta didik ingin ditanamkan kepada peserta didik selama ini, terbatas pada uji kompetensi memerlukan sebuah proses yang secara kognitif dan psikomotorik. simultan dan berkesinambungan. Menurut Pendidikan karakter merupakan proses Lickona (2012), terdapat tiga komponen yang dimulai dari pemahaman, pembentukan karakter baik, yaitu pembiasaan hingga ke pembudayaan, mengetahui hal yang baik (Moral sehingga menjadi perilaku hidup sehariKnowing), keinginan untuk melakukan hari, Hambatan yang dihadapi guru bisa yang baik (Moral Feeling), dan melakukan hal yang baik (Moral Behavior). Ketiga hal ini diperlukan untuk mengarahkan dan membentuk pendewasaan moral.

Salah satu kendala praktek pendidikan karakater yang tidak komprehensif disekolah terdapat pada guru, kendala tersebut antara lain rendahnya pengetahuan guru terhadap konsep pendidikan karakter serta bagaimana implementasi pendidikan karakter dalam proses kegiatan pembelajaran, selain itu kurangnya jumlah guru yang secara eksplisit mendisain kegiatan pembelajarannya dalam gembangkan pendidikan karakter. Menurut Triatmo (2010), sebagian besar guru belum mampu menyusun perangkat observasi yang menggambarkan karakter peserta didik secara tepat. Perumusan indikator dan deskriptor tentang perilaku disiplin dapat sangat bervariasi diantara bertambah bila kemudian guru diminta mengevaluasi hasil pembelajarannya dengan target pendidikan karakter yang telah ditetapkan.

\section{Guru sebagaiRole Model pengembangan karakter peserta didik}

Tantangan guru sebagai guru selain mampu mentransfer ilmu pengetahuan, harus mampu menjadikan dirinya sebagai role model bagi pembelajar.Bashir (2014) menyatakan bahwa, "Seorang role modeladalah orang yang menginspirasi dan mendorong kita untuk berjuang untuk hal yang besar, membangkitkan potensi maksimal kita dan mampu melihat yang terbaik dalam diri kita. Seorang role mode/ bisa setiap orang; orang tua, saudara atau teman, tetapi beberapa role mode/ yang memiliki pengaruh kuat dan dapat mengubah kehidupan are guru. Pandangan di atas 
dapat dinyatakan bahwa seorang guru harus mampu memberikan perbaikan yang signifikan terhada kepribadian peserta didik. Guru memiliki pengaruh jangka panjang bagi kehidupan peserta didik mereka, dan guru terhebat menginspirasi peserta didiknya.

Thoifuri (2008 ) menambahkan bahwa karakter sosial dan pribadi guru dapat diwujudkan dalam bentuk: (a) seorang guru harus cerdas dan berwawasan, (b) seorang guru harus terus meningkatkan pengetahuannya, (c) seorang guru harus yakin terhadap keabsahan dan manfaat pelajaran yang disampaikan, (d) seorang guru harus obyektif dalam menyelesaikan masalah, (e) seorang guru harus memiliki dedikasi, motivasi dan loyalitas yang baik, (f) seorang guru harus bertanggung jawab terhadap kualitas dan kepribadian yang bermoral, (g) seorang guru harus mampu memperbaiki perilaku peserta didik, (h) seorang guru harus menjauhkan dirinya dari penghargaan dan pujian, (i) seorang guru harus mampu mengaktualisasikan materi pelajaran disajikan, dan (j) seorang guru harus memiliki banyak insiatif atau prakarsa sesuai dengan perkembangan teknologi.

Peran guru sebagai role model tidak hanya meliputi sikap dalam belajar, bertindak dan berpenampilan.Namun tak kalah penting adalah role model dalam berkomunikasi.Peran komunikasi guru dalam hal ini sering kali dianggap kurang penting dan tidak memberi pengaruh terhadap perkembangan peserta didik. Padahal, bahasa yang digunakan untuk berinteraksi dalam kehidupan, khususnya kepada peserta didik dalam kegiatan pembelajaran, akan memberi pengaruh besar terhadap perkembangan mental atau jiwa peserta didik. Seseorang yang menggunakan pilihan kata yang tepat, ungkapan sopan, dan struktur kalimat yang baik saat berbicara menunjukkan bahwa orang tersebut memiliki kepribadian yang baik (Syahrul, 2014). Dalam dunia pendidikan, kesantunan berbahasa merupakan cara guru berinteraksi dengan peserta didik. Hal ini penting untuk membangun hubungan emosional yang baik antara guru dan peserta didik serta dapat membangun kegiatan belajar mengajar yang lebih kondusif. Penggunaan kalimat positif dan memotivasi dibutuhkan untuk menumbuhkan semangat belajar peserta didik.

Mata kuliah Pendidikan Karakter di Fakultas keguruan dan IImu Pendidikan

Di lingkungan pendidikan tinggi khususnya di Fakultas Keguruan dan IImu Pendidikan, pendidikan perilaku yang 
berkarakter untuk mahasiswa belum banyak dilakukan secara formalsehingga proses pendidikan karakter belum banyak menyentuh pembinaan karakter mahasiswa. Sebagai penghasil caloncalon guru profesional Fakultas Keguruan dan IImu Pendidikan dituntut mampu merancang kegiatan pembelajaran yang mampu mengembangkan siswanya menjadi seorang siswa yang berkarakter - Mahasiswa fakultas keguruan selain harus memahami ilmu kependidikan juga harus memiliki etika yang baik dalam dirinya sehingga berdampak pada perilakunya sehari-hari, diharapkan nantinya akan memungkinkan mahasiswa-mahasiswa calon pendidik tersebut tersebut terbiasa berperilaku etis. Perilaku etis inilah yang nantinya akan dijadikan pedoman menginternalisasikan karakter dalam profesinya sebagai pendidik

Berdasarkan observasi awal yang dilakukan oleh penulis, Realita yang tampak pada mahasiswa keguruanselain hanya memfokuskan diri pada nilai akhir (IPK) dan berusaha cepat menyelesaikan masa kuliah, juga bersikap tidak acuh terhadap pentingnya etika, perilaku dan pengembangan karakter.Sehingga muncul kecenderungan lahirnya guruguru yang kurang mampu menginmplementasikan pendidikan karakter. Hal ini disebabkan mahasiswa keguruan diharapkan tidak hanya akan menjadi seorang pendidik yang menerapkan keilmuan sebagai disiplin ilmu yang dikuasainya, tetapi juga harus menjadi lulusan yang bertanggung jawab berdasarkan gelar yang dimiliki.

Kondisi tersebut menggambarkan urgensi pendidikan karakter yang memerlukan pembelajaran secara komprehensif dan terpadu khusus untuk mahasiswa di fakultas keguruan dan IImu pendidikan. Perlunya pendidikan karakter dijadikan mata kuliah bertujuan agar mahasiswa keguruan dapat mengetahui konsep-konsep pendidikan karakter yang lebih menyeluruh, cara implementasi pendidikan karakter, serta strategi pembelajaran berbasis karakter. Proses pembelajaran mata kuliah pendidikan karakter diarahkan pada upaya memberikan motivasi dan penguatan kepada mahasiswa keguruan melalui kegiatan pembelajaran yang mengaktifakan kemandirian mahasiswa melalui pemberian kesempatan mengeluarkan gagasan, mencari informasi dari berbagai sumber, memecahkan permasalahan moral dan karakter serta melaksanakan tugas yang merupakan aplikasi dari konsep-konsep pendidikan karakter yang dipelajari. Selain kesiapan calon guru dlam 
menerapkan pendidikan karakter di sekolah, Pendidikan karakter akan berdampak positif pada perilaku mengajar saat menempuh perkuliahan.

\section{PENUTUP}

\section{Kesimpulan}

Mencermati hasil penelitian menunjukkan bahwa hampir seluruh mahasiswa Ilmu Pendidikan Universitas Negeri Gorontalo tidak paham mengenai pendidikan karakter, tidak paham bagaimana implementasi pendidikan karakter dan tidak tau cara mengajarkan pendidikan karakter kepada siswa. data ini menggambarkan bahwa pengetahuan terkait pengembangan mahasiswa yang merupakan calon-calon guru bertentangan dengan konteks pencapaian tujuan pendidikan karakter, dimana guru merupakan ujung tombak keberhasilan pencapaian tujuan pendidikan karakter. Guru, merupakan sosok yang digugu dan ditiru, memiliki peran penting dalam terwujudnya proses pembentukan karakter peserta didik.

Dalam mendukung peran guru dalam pembentukan karakter peserta didik, guru dituntut memahami dan memiliki karakter yang kuat serta mampu mentransfer penguatan dan motivasi terhadap peserta didik, guru juga harus mampu menjadi pendidik yang memberi teladan (Role mode) sehingga guru diberi ruang dihati perserta didik sebagai guru yang diidolakan, guru yang dicintai dan disayangi peserta didik. Kemampuan pengembangan karakter yang berkualitas oleh guru tidak diperoleh secara Instan.Guru memerlukan proses inputan karakter-karakter yang baik baik dari kegiatan pelatihan-pelatihan pengembangan karakter serta lingkungan sekolah yang mendukung pengembangan pendidikan krakter, selain itu yang sering terabaikan adalah pentingnya pembelajaran karakter terhadap caloncalon guru, pembelajaran selama perkuliahan yang berkarakter sering terlewatkan dari kurikulum pembelajaran di fakultas keguruan dan IImu Pendidikan. Sehingga ditemukan banyak guru-guru yang tidak memiliki karakter positif.Selaint itu, integrasi pendidikan karakter dalam kegiatan perkuliahan di fakultas keguruan dirasa belum mampu melahirkan caloncalon guru yang berkarakter.Oleh karena itu Pendidikan karakter di Fakultas Keguruan sangat urgen dilaksanakan. Pemberian materi karakter harus diberikan secara terpadu sebagai mata kuliah, sehingga mahasiswa difakultas keguruan akan lebih memahami konsepkonsep pendidikan karakter, implementasi pendidikan karakter dan bagaimana 
membentuk kualitas karakter peserta didik disekolah.

\section{DAFTAR PUSTAKA}

Aan Komariah dan Djam'an Satori. (2010). Metodologi Penelitian Kualitatif Bandung :Alfabeta.

Bashir, S. (2014). Teacher as A Role Model and Its Impact on the Life of Female Students.

International Journal of Research Granthaalayah. [Shakila et al.*, Vol.1(Iss.1):August,2014

Danin, S. (2010). Profesionalisasi dan Etika Profesi Guru. Bandung: Alfabeta.

Gunawan, Heri. (2012.) Pendidikan Karakter; Konsep dan Implementasi. Bandung: Alfabeta

Kunandar. (2008). Guru Profesional: Implementasi Kurikulum Tingkat Satuan Pendidikan

(KTSP) Dan Sukses Dalam Sertifikasi Guru. Jakarta: PT Raja Grafindo Persada.

Lickona, T. (2012). Mendidik untuk membentuk karakter: Bagaimana sekolah

dapat memberikanpendidikan tentang sikap hormat dan bertanggung jawab. Diterjemahkan oleh: Wamaungo.Jakarta: PT. Bumi Aksara

Leonie Francisca dan Clara R.P. Ajisuksmo. (2016). Kompetensi Guru Pada Pendidikan

Karakter Berdasarkan Komponen Pembentukan Karakter Di Sebuah Lembaga Pendidikan Non-

Formal. Jurnal Pemberdayaan Masyarakat Vol. 3 No. 1 Mei 2016

Nazir. (2005). Metode Penelitian. Jakarta : Ghalia Indonesia

Nana Syaodih. (2007). Metode Penelitian Pendidikan. Bandung: PT Remaja Rosdakaya

Nana Syaodih. (2010). Metode Penelitian Pendidikan. Bandung: PT Remaja Rosdakaya

Moleong, Lexy J. (2004). Metodologi penelitian kualitatif. Bandung : Remaja Rosdakarya

Prof. DR Sugiyono.(2015). Metode Penelitian Kuantitatif Kualitatif dan R\&amp;D. Bandung : CvAlfabeta 
Raka, G., Mulyana, Y., Markam, S.S., Pendidikan, Mei 2010, Th. XXIX Semiawan, C.R., Hasan, S.H., EdisiKhusus Dies Natalis UNY Bastaman, H.D., \&amp;

Nurachman, N. (2011). Pendidikan karakter di sekolah: Dari gagasan ke tindakan. Jakarta: PT.Elex Media Komputindo

Suryadi \&amp; Turmudi. (2011). Kesetaraan Didactical Desing Ressearch (DDR) Dengan

Matematika Realistik Dalam Pengembangan Pembelajaran Matematika Makalah disajikan padaSeminar Nasional UNS 26 November 2011.Syahrul.(2014). Language Politeness and Character Education in Indonesian Language Learning Based on Curriculum 2013. ISBN: 978-60217017-4-4.

Sugiyono. (2011).

MetodePenelitianKuantitatif,

Kualitatif, danR\&amp;D. Bandung:

Alfabeta

Thoifuri.(2008). Menjadi Guru Inisiator. Semarang. Rasail Media Group.

Triatmo.(2010).

TantanganImplementasiPendidika

nKarakter di Sekolah.Cakrawala 